\title{
Peningkatan Kemampuan Berkomunikasi dengan Menerapkan Metode Bercakap-Cakap pada Siswa Kelompok A TK Aisyiyah 1 Sawahan
}

\author{
Hery Setiyatna \\ IAIN Surakarta \\ e-mail: herysetiya@gmail.com
}

\begin{abstract}
The research aims to report the improvement of the kindergarten students' communication skill by implementing the chatting technique. This study is a collaborative action research. The subjects are group A kindergarten students at TK Aisyiyah 1 Sawahan. The data is collected by field notes then analyzed with comparative analysis and interactive techniques. Performance indicators for this research are the average child reaches the ability to communicate for (1) $50 \%$ in the first cycle, (2) $60 \%$ in the second cycle, and (3) $75 \%$ in the third cycle. This study was conducted in three cycles and each cycle consists of: (1) Planning, (2) Acting, (3) Observing and (4) Reflecting.The result of this research indicated that chatting technique can improve the communication skill of group A kindergarten students in TK Aisyiyah 1 Sawahan, as teachers doing some reflections, the process of learning activities focused on students, and students were actively involved in the activities. The percentage of students communication skill before the action was less than 25\%, the percentage of students' ability to communicate after the action on the first cycle increased to $43.75 \%$, in the second cycle increased to $75 \%$, in the third cycle increased to $93.75 \%$.
\end{abstract}

Keywords: chatting technique, communication skill, Group A kindergarten students 


\section{Pendahuluan}

Perkembangan kemampuan siswa adalah suatu proses perubahan dimana siswa belajar menguasai tingkat yang lebih tinggi dari berbagai aspek. Salah satu aspek penting dalam perkembangan adalah aspek perkembangan bahasa. Bahasa merupakan alat komunikasi yang sangat penting dalam kehidupan manusia. Pendidikan Anak Usia Dini (PAUD) merupakan suatu upaya pembinaan yang ditujukan kepada anak sejak lahir sampai dengan usia enam tahun melalui pemberian rangsangan pendidikan untuk membantu pertumbuhan dan perkembangan jasmani dan rohani. Menurut UU SPN Nomor 20 Tahun 2003 bahwa pendidikan adalah usaha sadar dan terencana untuk mewujudkan suasana belajar dan proses pembelajaran agar peserta didik secara aktif mengembangkan potensi dirinya untuk memiliki kekuatan spiritual keagamaan, pengendalian diri, kepribadian, kecerdasan, akhlak mulia, serta keterampilan yang diperlukan dirinya, masyarakat, bangsa dan Negara. Pendidikan bagi anak usia dini adalah pemberian upaya untuk menstimulasi, membimbing dan menyediakan kegiatan pembelajaran yang akan menghasilkan kemampuan dan keterampilan pada anak. Pendidikan TK/RA merupakan salah satu bentuk satuan pendidikan anak usia dini pada jalur pendidikan formal yang menyelenggarakan program pendidikan umum dan pendidikan keagamaan Islam bagi anak berusia empat tahun sampai enam tahun. Menurut Guilford dalam Hildebrand (1986:216), untuk membantu perkembangan kognitif anak perlu memperoleh pengalaman belajar yang dirancang melalui kegiatan mengobservasi dan mendengarkan secara tepat.

Berbicara sebagai suatu proses komunikasi, proses perubahan wujud ujaran atau bunyi bahasa yang bermakna, yang disampaikan kepada orang lain. Berbicara merupakan suatu peristiwa penyampaian maksud (ide, pikiran, perasaan) seseorang kepada orang lain dengan menggunakan bahasa lisan. Menurut Elizabeth Hurlock (1995:176), bahwa bicara adalah bentuk bahasa yang menggunakan artikulasi atau kata-kata yang digunakan untuk menyampaikan maksud. Isah Cahyani (2004:65), menegaskan bahwa "Anak belajar berbicara dengan cara berinteraksi dengan lingkungannya, selain itu lingkungan memberikan pelajaran pula terhadap tingkahlaku, ekspresi dan menambah perbendaharaan kata. Menurut Berelson dan Stainer 
dalam Fajar (2009:32). Komunikasi adalah proses penyampaian informasi, gagasan, emosi, keahlian dan lain-lain melalui penggunaan simbol-simbol seperti kata-kata, gambar-gambar, angka-angka. Moeslichatoen (2004:91) mengatakan bahwa bercakap-cakap merupakan salah satu metode pembelajaran di TK yang dilaksanakan dengan cara saling mengomunikasikan pikiran, perasaan, dan kebutuhan secara verbal serta mewujudkan kemampuan bahasa reseptif dan bahasa ekspresif.

Kajian dua hasil penelitian yang relevan dari penelitian Putri Ayu Handayani, mengkaji pentingnya peningkatan keterampilan berbicara pada Anak Usia Dini melalui metode bercakap-cakap dan Risky Ramadani mengkaji bagaimana meningkatkan keterampilan berbicara melalui metode bercakap-cakap dengan media gambar pada Anak Kelompok B2 di TK Aisyiyah Randubelang. Berbeda dengan dua penelitian di atas, penelitian ini lebih fokus mengkaji pada bagaimana meningkatkan kemampuan berkomunikasi dengan menerapkan metode bercakap-cakap pada Siswa Kelompok A TK Aisyiyah 1 Sawahan Ngemplak Boyolali Tahun Pelajaran 2015/2016, sehingga penelitian ini berbeda dengan dua penelitian sebelumnya.

Hipotesis tindakan yang diajukan dalam penelitian ini, adalah "Penerapan metode bercakap-cakap dapat meningkatkan kemampuan berkomunikasi pada siswa Kelompok A TK Aisyiyah 1 Sawahan Ngemplak Boyolali Tahun Pelajaran 2015/2016".Temuan yang diharapkan melalui proses kegiatan penelitian ini adalah bahwa para mahasiswa dan dosen di Jurusan PGRA IAIN Surakarta memperoleh bukti baru terhadap realita di lapangan yang menegaskan kebenaran bahwa dengan menerapkan Metode Bercakap-cakap dapat meningkatkan Kemampuan Berkomunikasi pada Siswa Kelompok A TK Aisyiyah 1 Sawahan Ngemplak Boyolali.Penelitian ini bertujuan untuk mendeskripsikan pelaksanaan tindakan dalam meningkatkan kemampuan berkomunikasi melalui metode bercakap-cakap pada siswa Kelompok A TK Aisyiyah 1 Sawahan Ngemplak Boyolali Tahun Pelajaran $2015 / 2016$.

\section{Metode Penelitian}

Penelitian ini merupakan penelitian tindakan kelas yaitu suatu bentuk kajian yang bersifat reflektif oleh pelaku tindakan yang dilakukan untuk meningkatkan 
kemantapan rasional dari tindakan-tindakan mereka dalam melaksanakan tugas, memperdalam pemahaman terhadap tindakan-tindakan yang dilakukan itu serta memperbaiki kondisi dimana praktek-praktek pembelajaran tersebut dilakukan. Penelitian dilakukan secara kolaboratif antara kepala sekolah, guru tetap dan peneliti. Kreativitas guru sangat berperan dalam menentukan keberhasilan penyampaian materi pembelajaran kepada anak untuk diterapkan dalam kehidupan sehari-hari. Penelitian dilaksanakan pada bulan Mei sampai Juli 2016 di TK Aisyiyah 1 Sawahan Ngemplak Boyolali. Subyek Penelitian yang melaksanakan tindakan adalah Guru Kelompok A dan subyek penelitian yang menerima tindakan adalah Siswa Kelompok A TK Aisyiyah 1 Sawahan Ngemplak Boyolali. Data penelitian dikumpulkan dengan observasi dengan membuat catatan lapangan. Data yang sudah terkumpul dianalisis dengan teknik analisis komparatif dan teknik analisis interaktif. Teknik analisis komparatif yaitu membandingkan rata-rata pencapaian kemampuan berkomunikasi setiap siklus dengan indikator kemampuan berkomunikasi setiap siklus. Sedangkan teknik analisis interaktif dilakukan dengan melihat pedoman observasi kemudian diambil kesimpulan.

Indikator kinerja sebagai kriteria keberhasilan penelitian ini apabila terjadi peningkatan kemampuan berkomunikasi dengan menerapkan metode bercakap-cakap pada Siswa Kelompok A TK Aisyiyah 1 Sawahan Ngemplak Boyolali Tahun Pelajaran 2015/2016 dilihat dari kinerja tiga siklus berturut-turut sebagai target kinerja, keberhasilan meningkatkan kemampuan berkomunikasi pada setiap siklus adalah (1) jika rata-rata kemampuan berkomunikasi anak mencapai 50\% merupakan Indikator Kinerja pada Siklus I, (2) jika rata-rata kemampuan berkomunikasi anak mencapai 60\% merupakan Indikator Kinerja pada Siklus II dan (3) jika rata-rata kemampuan berkomunikasi anak mencapai 75\% merupakan Indikator Kinerja pada Siklus III.

Penelitian yang dilakukan ini mengacu pada model penelitian Kemmis dan Mc Taggart. Mc.Taggart menggunakan siklus sistem spiral refleksi diri yang mulai dengan rencana, tindakan, observasi dan refleksi, perencanaan kembali merupakan dasar untuk suatu ancang-ancang pemecahan permasalahan (Kasihani Kasbolah, 1998:113). 
Penelitian tindakan kelas model Kemmis dan Mc Taggart digambarkan sebagai berikut:

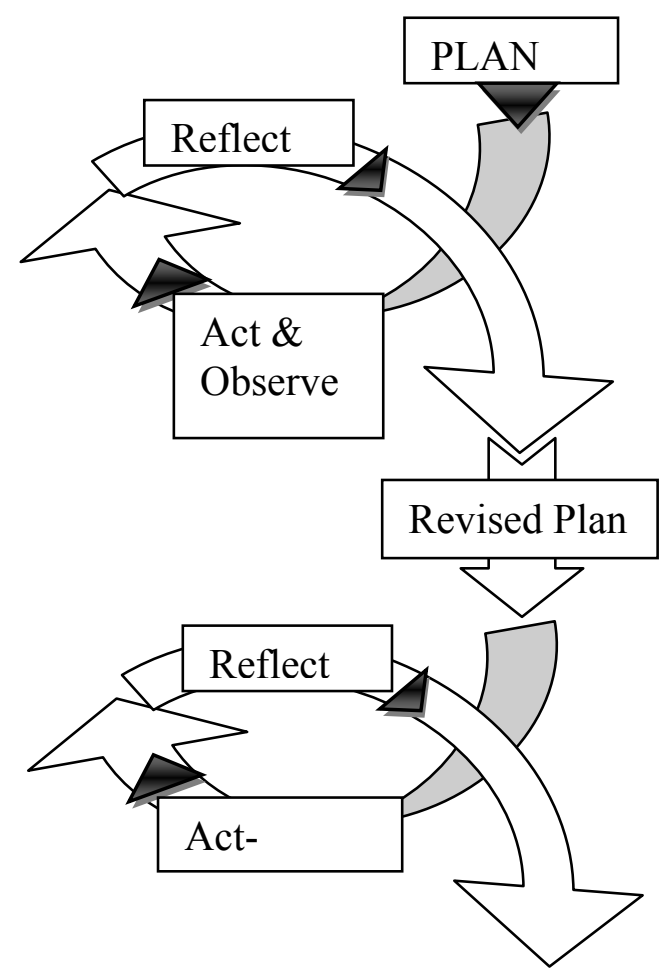

Gambar 1 PTK Model Kemmis \& McTaggart

Pengamatan dilakukan pada waktu tindakan sedang dilakukan. Jadi, pelaksanaan tindakan dan pengamatan berlangsung pada waktu yang sama (Suharsimi Arikunto, 2007:19). Penelitian tindakan kelas ini menggunakan siklus dalam kegiatan pembelajaran. Kegiatan pembelajaran pada siklus pertama sebagai dasar untuk menentukan langkah selanjutnya atau apabila siklus kedua diperlukan. Pada siklus pertama dilakukan perencanaan dilanjutkan pelaksanaan dan pengamatan kegiatan belajar mengajar dan pada akhir kegiatan pembelajaran dalam siklus pertama dilakukan evaluasi dan refleksi peningkatan hasil belajar anak, kemungkinan kesulitan dan kendala yang dijumpai selama roses pembelajaran berlangsung.

Penelitian ini dilakukan dengan menggunakan metode Penelitian Tindakan Kelas terdiri dari tiga Siklus. Langkah-langkah dalam setiap siklus terdiri dari: (a) Planning, (b) Acting, (c) Observing dan (d) Reflecting. 


\section{Hasil Penelitian}

Sebelum melakukan tindakan dalam penelitian, peneliti melakukan observasi pra siklus yaitu dengan melakukan pengamatan untuk mengetahui kemampuan komunikasi anak sebelum dilaksanakan tindakan dengan menerapkan metode bercakap-cakap. Penelitian ini dilaksanakan pada kelompok A dengan jumlah murid 16 anak. Hasil pengamatan sebelum tindakan diperoleh rata-rata prosentase kemampuan komunikasi anak diperoleh kurang dari $25 \%$.

Pada siklus I yaitu anak mampu menunjukkan gambar yang diminta, cerita tentang gambar yang telah disediakan dan mampu berbicara lancar dengan menggunakan kalimat yang komplek terdiri dari 5-6 kata. Berdasarkan hasil tabulasi diperoleh rata-rata prosentase pembelajaran bercakap-cakap anak 1 kelas sebesar 43,75\%. Prosentase tersebut sudah mencapai hasil kemampuan dari skor maksimal yang ditargetkan Peneliti pada pelaksanaan siklus I yaitu $\geq 25 \%$. Dari analisis di atas dapat disimpulkan bahwa kemampuan komunikasi anak tidak merata. Sembilan anak belum mencapai kemampuan dan 7 anak sudah mencapai kemampuan sesuai dengan skor maksimal yang ditentukan peneliti. Oleh karena itu perlu adanya tindakan untuk menindaklanjuti permasalahan tersebut dalam rangka meningkatkan kemampuan komunikasi anak. Karena merasa target penelitian belum tercapai, peneliti melanjutkan melaksanakan siklus II. Berdasarkan hasil tabulasi diperoleh rata-rata prosentase peningkatan kemampuan komunikasi anak 1 kelas sebesar 18,75\%. Prosentase tersebut belum mencapai hasil kemampuan dari skor maksimal yang ditargetkan peneliti pada pelaksanaan siklus I.

Komunikasi anak sudah baik dan mampu mencapai butir amatan yang mencapai skor sesuai yang ditargetkan peneliti. Berdasarkan hasil tabulasi diperoleh rata-rata prosentase peningkatan kemampuan komunikasi anak 1 kelas sebesar 75\%. Persentase tersebut telah mencapai hasil kemampuan dari skor maksimal yang ditargetkan peneliti pada pelaksanaan siklus II yaitu $\geq 50 \%$. Pada siklus II ini dalam melakukan kegiatan anak-anak terlihat sangat senang mengikuti kegiatan pembelajaran, karena sebisa mungkin guru berusaha menciptakan suasana belajar yang menarik bagi anak. Walaupun masih ada beberapa anak yang belum memperhatikan penjelasan dari guru. Anak yang belum mampu mencapai target yang 
ditentukan peneliti yaitu 25\% masih ada 4 anak. Persentase tertinggi yang dicapai anak adalah 75\%. Persentase pembelajaran bercakap-cakap pada siklus II ini sudah meningkat, yaitu mencapai $31,25 \%$. Hasil persentase ini sudah dikatakan meningkat dibandingkan dengan siklus I. Sehingga kemampuan berkomunikasi anak sudah baik dan mampu mencapai butir amatan yang mencapai skor sesuai dengan yang ditargetkan peneliti. Namun karena masih ada 4 anak yang belum mencapai keberhasilan maka penelitian dilanjutkan pada siklus III.

Komunikasi anak sudah baik dan mampu mencapai butir amatan yang mencapai skor sesuai yang ditargetkan peneliti. Berdasarkan hasil tabulasi diperoleh rata-rata prosentase peningkatan kemampuan komunikasi anak 1 kelas sebesar 93,75\%. Persentase tersebut telah mencapai hasil kemampuan dari skor maksimal yang ditargetkan peneliti pada pelaksanaan siklus III yaitu $\geq 75 \%$. Pada siklus III ini dalam melakukan kegiatan anak-anak terlihat sangat senang mengikuti kegiatan pembelajaran, karena sebisa mungkin guru berusaha menciptakan suasana belajar yang menarik bagi anak. Walaupun masih ada beberapa anak yang belum memperhatikan penjelasan dari guru. Anak yang belum mampu mencapai target yang ditentukan peneliti yaitu $6,25 \%$ masih ada 1 anak. Persentase pembelajaran bercakap-cakap pada siklus III ini kembali meningkat, yaitu mencapai 18,75\%. Hasil persentase ini sudah dikatakan meningkat dibandingkan dengan siklus I dan siklus II. Sehingga kemampuan berkomunikasi anak baik dan mampu mencapai butir amatan yang mencapai skor sesuai dengan yang ditargetkan peneliti.

Tabel 1 Peningkatan Kemampuan Ketrampilan Berkomunikasi Kelompok A

\begin{tabular}{|l|l|l|l|l|l|l|}
\hline \multirow{2}{*}{ Kategori } & \multicolumn{2}{|c|}{ Siklus I } & \multicolumn{2}{c|}{ Siklus II } & \multicolumn{2}{c|}{ Siklus III } \\
\cline { 2 - 7 } & Jumlah & $\%$ & Jumlah & $\%$ & Jumlah & $\%$ \\
\hline Rendah & 9 & 56.25 & 4 & 25 & 1 & 6.25 \\
\hline Sedang & 7 & 43.75 & 5 & 31.25 & 3 & 18.75 \\
\hline Tinggi & 0 & 0 & 7 & 43.75 & 12 & 75 \\
\hline
\end{tabular}




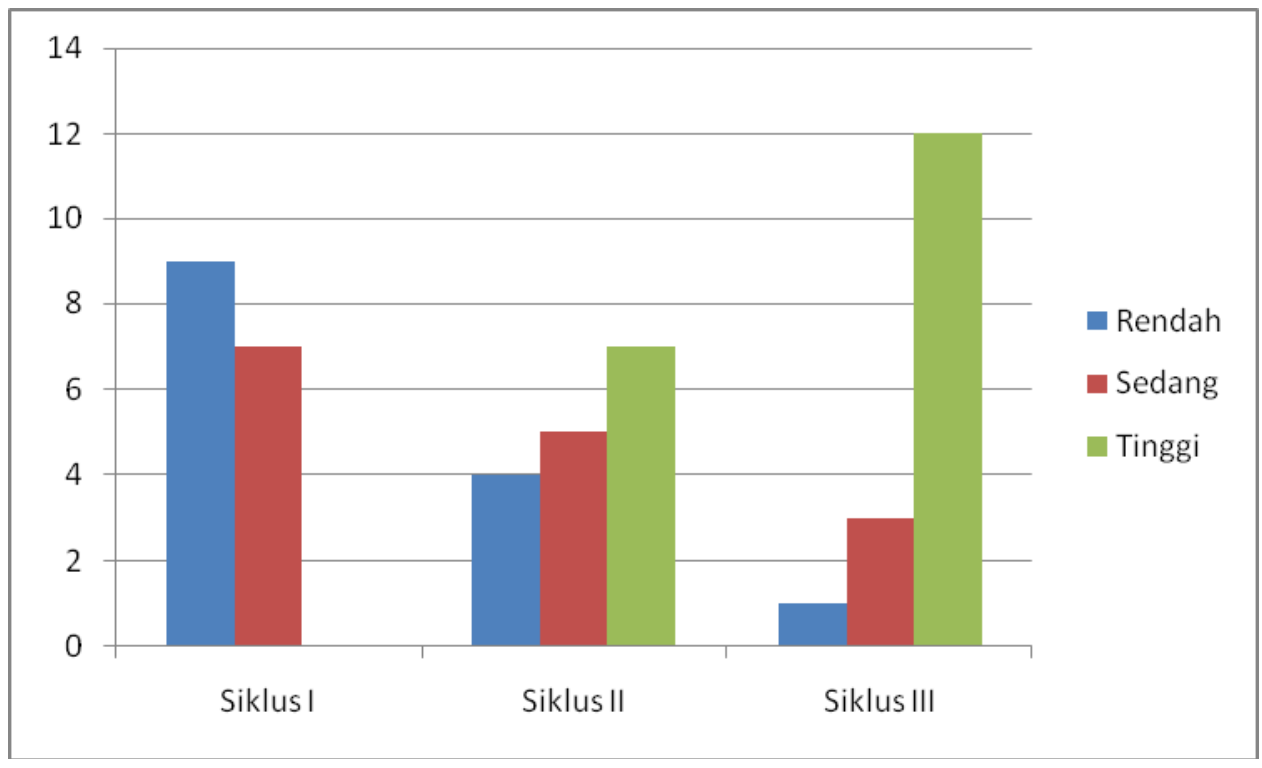

Grafik 1 Peningkatan Kemampuan Peserta Didik

Berdasarkan penelitian yang dilakukan pada siklus I, siklus II, dan siklus III dapat diketahui bahwa kemampuan berkomunikasi anak mengalami peningkatan. Persentase kemampuan berkomunikasi dari prasiklus ke siklus I mengalami peningkatan hanya sebesar $18,75 \%$, hal ini dikarenakan pada siklus I anak masih dalam proses pengenalan metode, alat dan media yang digunakan di siklus I, komunikasi anak dalam bercakap-cakap belum maksimal, masih kurang berani mengungkapkan ide dan gagasan sendiri. Persentase peningkatan kemampuan berkomunikasi dari siklus I ke siklus II mengalami peningkatan yang signifikan yaitu $31,25 \%$, hal ini dikarenakan anak-anak sudah mampu mengenal metode bercakapcakap, mampu menggunakan alat dan media dengan baik, anak mampu menunjukkan gambar yang diminta, anak sudah berani menceritakan tentang gambar yang disediakan, anak mampu berbicara lancar, anak mampu mendengarkan, menceritakan dan mampu mengurutkan isi gambar seri.

Persentase kemampuan berkomunikasi anak dari siklus II ke siklus III mengalami penurunan yaitu hanya mengalami peningkatan sebesar $18,75 \%$, hal ini dikarenakan anak-anak sudah mulai merasa jenuh dengan kegiatan yang diberikan sehingga daya konsentrasi anak sudah menurun, ramai sendiri, dan beberapa anak kurang memperhatikan guru. Peningkatan yang ditunjukkan di setiap siklus tidak 
Hery Setiyatna 45

Peningkatan Kemampuan Berkomunikasi dengan Menerapkan Metode Bercakap-Cakap pada

Siswa Kelompok A TK Aisyiyah 1 Sawahan

menunjukkan suatu kestabilan. Persentase peningkatan sebelum tindakan sampai dengan siklus I peningkatannya hanya mencapai 18,75\%. Hal ini disebabkan karena anak belum terbiasa menggunakan metode bercakap-cakap, dimana sebelumnya jarang sekali diberikan kegiatan bercakap-cakap menggunakan gambar seri. Pada siklus III peneliti mentargetkan tingkat pencapaian persentase $\geq 75 \%$. Hal ini dikatakan meningkat karena prosentase rata-rata kelas melebihi yang ditargetkan yaitu sebesar 93,75\%. Siklus I sampai dengan siklus II peningkatan persentase mencapai $31,25 \%$, ini terjadi karena pada siklus II anak mulai senang mengikuti kegiatan bercakap-cakap, serta adanya reward untuk setiap anak.

Berdasarkan hasil observasi diketahui bahwa kemampuan berkomunikasi setiap anak dalam kegiatan bercakap-cakap tidak sama. Hal ini dibuktikan masih ada beberapa anak yang sampai pada siklus II belum mampu memcapai persentase yang ditentukan oleh peneliti. Adapun jumlah anak yang belum mampu mencapai target yang ditentukan peneliti sebanyak 1 anak. Namun hal ini tidak menjadi masalah mengingat kemampuan anak berbeda-beda. Selain itu rata-rata persentase 1 kelas sudah meningkat.

Adapun anak yang mengalami peningkatan kurang karena anak yang memiliki daya tangkap kurang dan lambat dalam belajar, sedangkan anak yang lain kurang memiliki keberanian. Adapun anak yang mengalami peningkatan biasa karena sebagian besar anak ini pada dasarnya kemampuan belajarnya baik namun ketika proses pembelajaran berlangsung senang ramai dan tidak memperhatikan guru sehingga hasil yang diperoleh kurang optimal. Adapun anak yang mengalami peningkatan drastis merupakan anak yang mempunyai kemampuan belajar baik dan mempunyai daya konsentrasi baik ketika proses pembelajaran berlangsung. Berdasarkan hasil penelitian tersebut diatas maka penelitian ini telah mendukung adanya penelitian yang dilakukan oleh Masnur Muslich (2002) menyimpulkan bahwa dengan metode bercerita dapat meningkatkan kosa kata anak usia dini, terkait dengan wawasan dan pendapat guru pendidikan anak usia dini dalam pembelajaran kosa kata, semua guru berpendapat bahwa pembelajaran kosa kata sangat penting karena perbendaharaan kata bagi anak diperlukan untuk berkomunikasi sehari-hari dengan teman dan kepada orang lain. Semakin banyak anak mengenal kosa kata, semakin

| Volume. 2, No. 1, Januari-Juni 2017 
mudah anak berkomunikasi dan mengungkapkan perasaan dan gagasannya kepada orang lain.

\section{Kesimpulan}

Hasil penelitian tindakan kelas yang dilakukan secara kolaboratif antara peneliti dan guru kelas kelompok A di TK Aisyiyah 1 Sawahan Boyolali dapat disimpulkan bahwa penerapan metode bercakap-cakap dapat meningkatkan kemampuan berkomunikasi pada anak kelompok A di TK Aisyiyah 1 Sawahan Boyolali, dengan guru melakukan perbaikan pembelajaran antara lain proses kegiatan pembelajaran dipusatkan kepada siswa, siswa terlibat aktif dalam kegiatan, guru bertindak sebagai fasilitator dan tidak mendominasi dalam kegiatan pembelajaran. Hasil penelitian yang menunjukkan bahwa terjadi peningkatan persentase kemampuan berkomunikasi pada setiap siklus yaitu prosentase kemampuan berkomunikasi anak sebelum tindakan dengan metode bercakap-cakap adalah kurang dari 25\%. Persentase kemampuan berkomunikasi anak setelah tindakan pada siklus I meningkat mencapai 43,75\%. Persentase kemampuan berkomunikas anak pada siklus II setelah tindakan meningkat mencapai 75\%. Persentase kemampuan berkomunikasi anak pada siklus III setelah tindakan meningkat mencapai 93,75\%. Bertolak dari uraian tersebut di atas, dapat disimpulkan bahwa hipotesis yang dirumuskan telah terbukti kebenarannya, dengan demikian penggunaan metode bercakap-cakap dapat meningkatkan kemampuan berkomunikasi pada anak kelompok A di TK Aisyiyah 1 Sawahan Boyolali.

\section{Daftar Pustaka}

Fajar Marhaeni, 2009. Ilmu Komunikasi Teori dan Praktek. Yogyakarta: Graha Ilmu.

Hadisetyo. 2009. Meningkatkan Kemampuan Berbahasa Lisan Anak Didik melalui Metode Bercerita pada Kelompok B di Taman Kanak Kanak Aisyiyah VII Purnamandala Kecamatan Wonosobo Kabupaten Wonosobo. dalam http://hadistyo.wordpress.com/2009/11/14/penelitian-tindakan-kelas-meningkatkankemampuan-berbahasa-lisan-anak-didik-elalui-metode-bercerita-padakelompok-b-di-taman-kanak-kanak-aisyiyah-vii-purnamandala-kecamatanwonosobo-kabupaten-wonosobo/, diakses tanggal 10 Desember 2012 
Hery Setiyatna 47

Peningkatan Kemampuan Berkomunikasi dengan Menerapkan Metode Bercakap-Cakap pada

Siswa Kelompok A TK Aisyiyah 1 Sawahan

Jalaluddin Rakhmat, 2011. Psikologi Komunikasi. Bandung : PT. Remaja Rosdakarya.

Marzuki, 2002. Metodologi Riset. Yogyakarta: BPFE-UII.

Masitoh, dkk., 2004. Strategi Pembelajaran TK. Jakarta : Universitas Terbuka.

Masnur Muslich, 2009. Melaksanakan PTK itu mudah (Classroom Action Research). Jakarta: Bumi Aksara

Metode bercakap-cakap dalam http://pgtk--darunnajah.blogspot.co.id/2011/03/ metode-bercakap-cakap.html diakses pada 23 Juni 2016; 05.25

Moeslichatoen R, 2004. Metode Pengajaran di Taman Kanak -Kanak. Jakarta : PT Rineka Cipta.

Musfiroh Tadzirotun, 2008. Bermain Sambil Belajar dan Mengasah Kecerdasan. Jakarta : Departemen Pendidikan Nasional.

Nana Syaodih Sukmadinata, 2007. Metodologi Penelitian Pendidikan. Bandung : Remaja Karya.

Nasution, 2003. Metode Research (Penelitian Ilmiah). Jakarta: Bumi Aksara.

Nur Aeni, 2000. Metode Pengembangan Kemampuan Bahasa. Jakarta : Departemen Pendidikan Nasional.

Nurbiana Dhieni, dkk., 2005. Metode Pengembangan Bahasa. Jakarta : Universitas Terbuka.

Putri Ayu Handayani, t.th. Pentingnya Peningkatan Ketrampilan Berbicara pada Anak Usia Dini melalui Metode Bercakap-Cakap, Program Studi Pendidikan Luar Sekolah, STKIP Siliwangi Bandung dalam https://www.google.co.id/ ?gws_rd=cr\&ei=uqwSWOYyxOW8BNj3qdAJ\#q=Pentingnya + Peningkatan $+\mathrm{K}$ etrampilan+Berbicara + pada + Anak + Usia + Dini + melalui + Metode+BercakapCakap, diakses pada tanggal 23 Juni 2016; 05.45.

Risky Ramadani, 2014. Skripsi: Meningkatkan Keterampilan Berbicara Melalui Metode Bercakap-Cakap dengan Media Gambar pada Anak Kelompok B2 di TK ‘Aisyiyah Randubelang; Program Studi Pendidikan Guru Pendidikan Anak Usia Dini, Jurusan Pendidikan Prasekolah dan Sekolah Dasar, Fakultas Ilmu Pendidikan, UNY.

Santrock, 2007. Psikologi Pendidikan. Jakarta: Kencana.

Sugiyono, 2002. Metode Penelitian Administrasi. Bandung : Alfa Beta.

At.t. Volume. 2, No. 1, Januari-Juni 2017 
Peningkatan Kemampuan Berkomunikasi dengan Menerapkan Metode Bercakap-Cakap pada Siswa Kelompok A TK Aisyiyah 1 Sawahan

Suharsimi Arikunto, 2007. Penelitian Tindakan Kelas. Jakarta: PT Bumi Aksara . , 2005. Dasar-dasar Evaluasi Pendidikan. Jakarta: Bumi Aksara. , 2005. Prosedur Penelitian Suatu Pendekatan Praktek (Edisi Revisi IV). Jakarta: Rineka Cipta.

Sukardi Dewa Ketut, 2004. Pengantar Pelaksanaan Program Bimbingan dan Konseling di Sekolah. Jakarta: Rineka Cipta.

Wina Sanjaya, 2009. Penelitian Tindakan Kelas. Jakarta: Predana Media Group. 